\title{
ON NEW PROOFS OF WILKER'S INEQUALITIES INVOLVING TRIGONOMETRIC FUNCTIONS
}

\author{
Bai-Ni Guo, BaO-Min QiaO, Feng Qi AND Wei Li
}

Abstract. In the note, some new proofs for inequalities involving trigonometric functions are given.

Mathematics subject classification (2000): Primary 26D05.

Key words and phrases: Trigonometric function, Wilker's inequality, Bernoulli number.

\section{REFERENCES}

[1] Group of Compilation, Handbook of Mathematics, People's Education Press, Beijing, China, 1979. (Chinese)

[2] B.-N. GUO, W. LI, B.-M. QIAO AND F. QI, On new proofs of inequalities involving trigonometric functions, RGMIA Res. Rep. Coll. 3 (2000), no. 1, Art. 15, 167-170. Available online at http: //rgmia.vu.edu.au/v3n1.htm1

[3] SEn-Lin Guo AND FENG QI, Recursion formulae for $\sum_{m=1}^{n} m^{k}$, Zeitschrift für Analysis und ihre Anwendungen 18 (1999), no. 4, 1123-1130.

[4] J.-C. KuANG, Applied Inequalities (Changyong Budengshi), 2nd edition, Hunan Education Press, Changsha, China, 1993, page 349. (Chinese)

[5] H.-Q. Lin, J.-W. WANG AND P.-ZH. WANG, Proof for one of inequality, Communicated paper on the 7 -th Conference of Teaching and Scientific Research for Universities and Colleges of Henan Province, Anyang University, Anyang City, Henan, China, July 25-28, 1999, (Chinese)

[6] B.-N. Guo AND F. QI, Generalization of Bernoulli polynomials, Internat. J. Math. Ed. Sci. Tech. 33 (2002), no. 3, 428-431. RGMIA Res. Rep. Coll. 4 (2001), no. 4, Art. 10, 691-695. Available online at http://rgmia.vu.edu.au/v4n4.html

[7] Feng QI, Li-Hong CUI, AND SEN-Lin Xu, Some inequalities constructed by Tchebysheff's integral inequality, Mathematical Inequalities and Applications 2 (1999), no. 4, 517-528.

[8] Yong-Huan Shen, Zai-Zhong Liang, LÜ-Hu Xu, And QIAN-QIan CaI, Practical Handbook of Mathematics (Shìyòng Shùxué Shǒucè), Science Press, Beijing, China, 1992; Second Print, 1997; pp. 273-274, 778-780. (Chinese)

[9] J. S. Sumner, A. A. Jagers, M. Vowe, AND J. ANGLESIO, Inequalities involving trigonometric functions, The American Mathematical Monthly 98 (1991), no. 3, 264-267.

[10] J. B. Wilker, E 3306, The American Mathematical Monthly 96 (1989), no. 1, 55. 